\title{
Root-cause analysis of bacteraemia increase and surveillance data in hemodialysis
}

\section{Caroline POHL ep OUDIN, Patricia Sermande, Evelyne Lenormand, Johan Bardil, Ingrid Marianne}

East Reunion Hospital Group

\section{Objective}

To investigate the bacteraemia increase in haemodialysis sector based on data from specific dialysis nosocomial infections national network surveillance (DIALIN) and through an Association of Litigation and Risk Management protocol (ALARM).

\section{Introduction}

In 2017, the dialysis centre of East Reunion Hospital Group (ERHG) based in Saint-Benoit highlighted an increase in bacteraemia's rates. It was a significant rising compared to previous years. Indeed, ERHG is participating since 2013 to the France haemodialysis infections network surveillance (DIALIN) [1], created in 2005 and that is allowing assessing bacteraemia. DIALIN is a multicentre prospective permanent survey that has followed six voluntary centres in 2005 and forty-two in 2016. Objectives of this network are firstly to produce data about acquired infections in haemodialysis sector such as infection incidence rate and standardized ratios allowing centres to compare themselves and, secondly, to improve the quality of care .The current study describe how a root cause analysis has been conducted through the ALARM risk assessment methodology to set up action plans and to reduce the phenomenon [2] [3]

\section{Methods}

Five years (2013-2017) of ERHG haemodialysis data were obtained from the haemodialysis infections national network surveillance (DIALIN).

To investigate and to analyse clinical incidents, the French National Authority for Health (HAS) [2] recommends the use of an Association of Litigation And Risk Management (ALARM) protocol. It is a powerful method for the investigation and analysis of serious incidents by risks managers [4]. Well established in industries sectors, the ALARM method of investigation is well introduced in French healthcare system since the last ten years. It was used to provide root cause analysis of this phenomenon. Individual's risk factors of each patients (endogenous factors) have been analysed but these risks were identical every year. Thus, we focused on elements different in 2017 from previous years (exogenous factors). We practised audits about hand hygiene, standard precautions, catheter connection and disconnection practices.

Our investigations covered several domains of risks or contributary factors such as patient, professional workers, teams, clinical practices protocols, technical and organisational context, care management and Hospital regional health policy.

\section{Results}

Data from DIALIN pointed out that the ERHG bacteraemia's rate was similar or lower to the national network until 2016 ( $\mathrm{n}=0$ in 2016 or 1 in 2015 bacteraemia per year only in catheter's access vascular). No infections nor bacteraemia on fistula were noted as showned on figure 1 and figure 2. In 2016, there were 68 haemodialysis chronic patients, 8996 dialysis sessions and incidence of all infections was 0.11 over 1000 sessions. In 2017, there were 84 haemodialysis chronic patients, 10377 dialysis sessions and incidence of all infections is 0.77 over 1000 sessions. Bacteraemia's rate was higher than national network and ERHG previous years.

The analysis of potential causes by ALARM method gave us different explanations. First of all, an increase of dialysis sessions and patients number could explain the increase. Then, this method allowed us to highlight a lower hand hygiene indicator for the service and an equipment issue. A batch of extra-corporal-circuit line was defective and a national withdrawal of any batch was initiated thanks to the ERHG. Secondary, the human factors like recruitment of new members with non-compliance of internal 
processes, management and human resources issues, under stress work conditions, bad working atmosphere, communication issues between haemodialysis professional workers, contributed to the bacteraemia increase. The investigations had also highlighted a misuse of antiseptic serving to catheter 's connection and disconnection process. Some nurses did not respect the activity time of antiseptic and others nurses splashed the antiseptic instead of cleaned with a sterile wipe.

Responses have been taken to stop this issue including the cooperation of healthcare team with the support of hygiene expert team. Nevertheless, because of the multiplicity of risk factors and identified roots causes, the phenomenon has not been stop promptly. Despite a slowdown, the phenomenon persists in 2018. Actions have been decided to standardize practices, to work in pairs, and to improve hand hygiene. News equipments and an other antiseptic following national guidelines (alcoholic chlorhexidin $2 \%$ ) were chosen by a multidisciplinary team.

\section{Conclusions}

Bacteraemia for dialysis patients might evolve towards serious complications as endocarditis or death in worth cases. During this period, no deaths nor endocarditis linked to bacteraemia have been revealed. The use of a risk management protocol derived from the industry allowed finding roots causes and set up actions plans to solve the phenomenon. ERHG participation to the DIALIN surveillance is continuing.

\section{References}

1. CPIAS, Auvergne Rhône Alpes. Annual report DIALIN; 2016.

2. HAS, Gestion des risques, Grille ALARM. JAM, N¹4 août/septembre/octobre; 2010.

3. Reason JT. Human error.New york:Cambridge University Press; 1990.

4. Vincent C, Taylor-Adams S, Chapman EJ, Hewett D, Prior S, et al. 2000. How to investigate and analyse clinical incidents: clinical Risk Unit and Association of Litigation and Risk Management protocol. BMJ. 320(7237), 777-81. PubMed https://doi.org/10.1136/bmj.320.7237.777

\begin{tabular}{|c|c|c|c|c|c|c|c|}
\hline Years & $\begin{array}{l}\text { Number of } \\
\text { patients } \\
\text { (n) }\end{array}$ & $\begin{array}{c}\text { number of days } \\
\text { of vascular } \\
\text { acess use } \\
\text { (VAF+PF+KT)* }\end{array}$ & $\begin{array}{l}\text { Number of } \\
\text { bacteriemia on } \\
\text { vascular acess } \\
\text { site } \\
\text { (n) }\end{array}$ & \multicolumn{3}{|c|}{$\begin{array}{c}\text { Distribution of } \\
\text { vascular acess } \\
\text { sites } \\
\text { (\%) }\end{array}$} & $\begin{array}{c}\text { incidence rate } \\
\text { of acess site } \\
\text { bacteriemia at } \\
1000 \text { days of } \\
\text { use }\end{array}$ \\
\hline 2013 & 38 & 11133 & 1 & $\begin{array}{c}74 . \\
2\end{array}$ & - & $\begin{array}{c}25 . \\
8\end{array}$ & 0,09 \\
\hline 2014 & 46 & 14770 & 1 & $\begin{array}{c}69 . \\
6\end{array}$ & 3 & $\begin{array}{c}27 \\
4\end{array}$ & 0,07 \\
\hline 2015 & 61 & 19362 & 0 & $\begin{array}{c}64 . \\
3\end{array}$ & 4,3 & $\begin{array}{c}31 \\
4\end{array}$ & 0,00 \\
\hline 2016 & 68 & 23821 & 0 & $\begin{array}{c}69 . \\
8\end{array}$ & 2.7 & $\begin{array}{c}27 . \\
5\end{array}$ & 0,00 \\
\hline 2017 & 85 & 28123 & 7 & $\begin{array}{c}62 \\
6\end{array}$ & 3 & $\begin{array}{c}34 \\
4\end{array}$ & 0,25 \\
\hline
\end{tabular}

*VAF: venous arterio fistula; FP, prothetic fistula; $K T$ : central cotheter

Figure 1. Evolution of bacteriemia incidence hemodialysis vascular acess site in ERHG

ISDS Annual Conference Proceedings 2019. This is an Open Access article distributed under the terms of the Creative Commons AttributionNoncommercial 4.0 Unported License (http://creativecommons.org/licenses/by-nc/3.0/), permitting all non-commercial use, distribution, and reproduction in any medium, provided the original work is properly cited. 


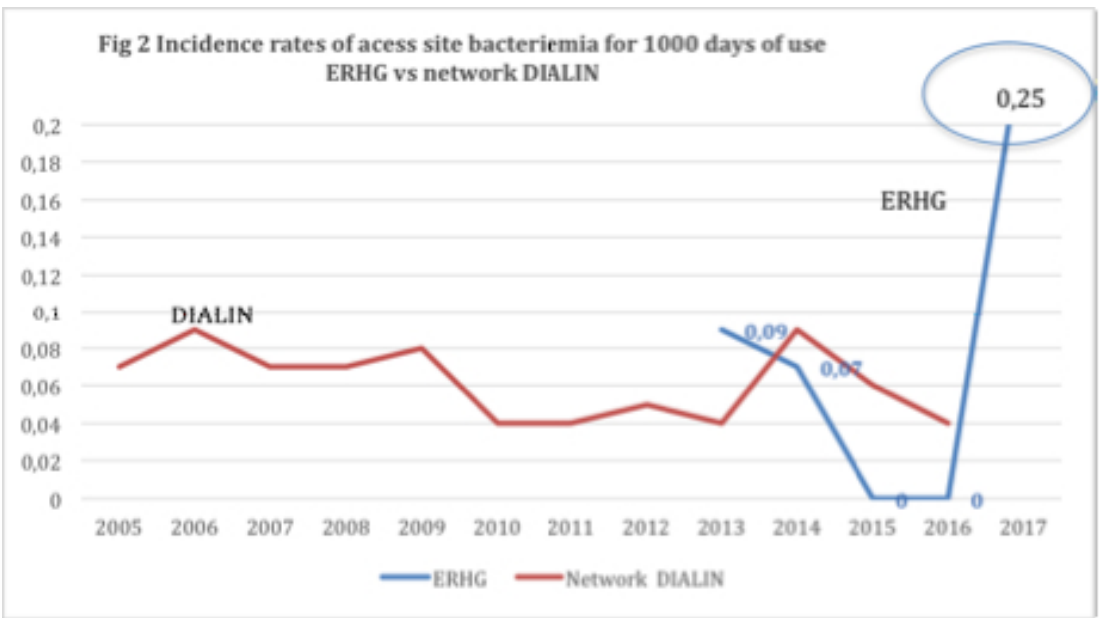

Figure 2. Incidence rates of acess site bacteriemia for 1000 days of use ERHG vs network DIALIN 